
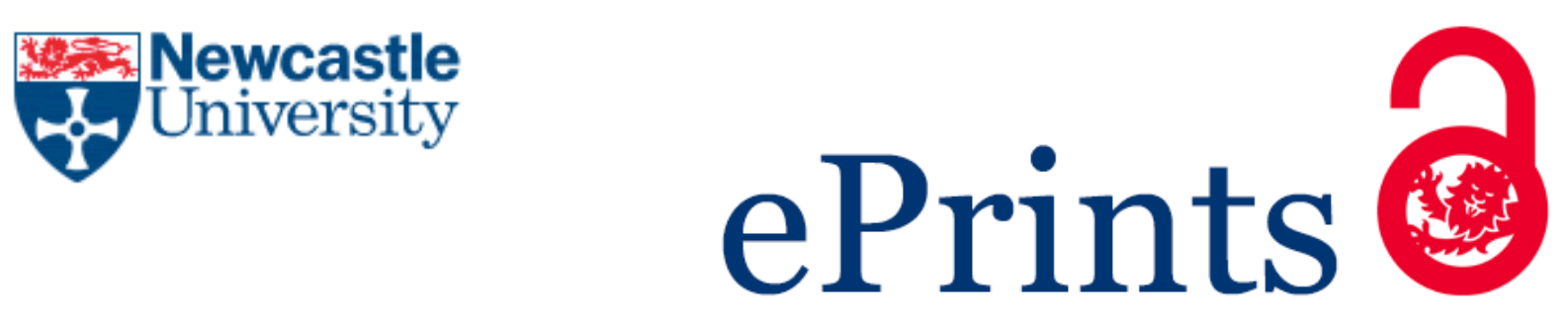

Velasquez-Orta SB, Heidrich O, Black K, Graham D.

Retrofitting options for wastewater networks to achieve climate change

reduction targets.

Applied Energy 2018, 218, 430-441.

\title{
Copyright:
}

(C) 2018. This manuscript version is made available under the CC-BY-NC-ND 4.0 license

DOI link to article:

https://doi.org/10.1016/j.apenergy.2018.02.168

Date deposited:

$12 / 04 / 2018$

Embargo release date:

15 March 2019

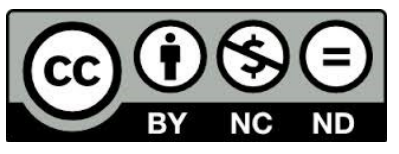

This work is licensed under a

Creative Commons Attribution-NonCommercial-NoDerivatives 4.0 International licence 


\section{Retrofitting options for wastewater networks to achieve climate change reduction targets}

Sharon B Velasquez-Orta ${ }^{1 *}$, Oliver Heidrich ${ }^{1 / 2}$, Ken Black ${ }^{3}$, David Graham ${ }^{1 *}$

${ }^{1}$ School of Engineering, Newcastle University, Newcastle upon Tyne, NE1 7RU England, UK..

${ }^{2}$ Research Fellow of the Tyndall Centre for Climate Change Research

${ }^{3}$ Northumbrian Water, Head Office, Abbey Road, Pity Me, Durham, DH1 5FJ, UK

*Corresponding Authors: Dr. Sharon B Velasquez-Orta, School of Engineering, Newcastle University, Newcastle upon Tyne, NE1 7RU, UK. E-mail: sharon.velasquez-orta@ncl.ac.uk Prof. David W Graham; School of Engineering, Newcastle University, Newcastle upon Tyne, NE1 7RU, UK. E-mail: d.graham@ncl.ac.uk. 


\begin{abstract}
An alternate approach to urban and regional planning is presented that considers the wastewater infrastructure from an energy consumption and carbon production perspective. The existing wastewater infrastructure from four counties in North East England region is investigated, which includes energy and carbon dioxide $\left(\mathrm{CO}_{2}\right)$ data from 87 wastewater treatment plants (WWTPs) (16 activated sludge (AS) and 71 biofilter (BF) plants) and 196 pump stations across the region. This study provides a rigorous and novel way of justifying new investments for retrofitting treatment technologies to the wastewater network. Mass and energy balances are performed across the network utilising a spread-sheet based model. Overall, energy use and $\mathrm{CO}_{2}$ emissions are greatest in biological wastewater treatment (relative to other network elements) with estimated median levels of $0.37 \mathrm{kWh} / \mathrm{m}^{3}$ and $0.40 \mathrm{~kg}$ $\mathrm{CO}_{2} / \mathrm{m}^{3}$, respectively, per waste volume processed. However, energy-use and $\mathrm{CO}_{2}$ emissions differed according to treatment technology with AS plants using significantly more energy (median $\left.=0.4 \mathrm{kWh} / \mathrm{m}^{3}\right)$ and producing more $\mathrm{CO}_{2}$ (median $=0.4 \mathrm{~kg}-\mathrm{CO}_{2} / \mathrm{m}^{3}$ ) than $\mathrm{BF}$ plants (medians: $0.2 \mathrm{kWh} / \mathrm{m}^{3}$ and $0.3 \mathrm{~kg}-\mathrm{CO}_{2} / \mathrm{m}^{3}$, respectively). Hence, directed interventions within WWTPs themselves will have the greatest positive influence on energy use and $\mathrm{CO}_{2}$ emissions. Given water companies are often locked-in with their infrastructure, retrofitting existing treatment networks is strongly suggested. For example, adding BF pre-treatment to existing AS plants will reduce energy use, whereas anaerobic or photosynthetic technologies may be useful for reducing energy and $\mathrm{CO}_{2}$ emissions in new-builds. This study confirms energy and carbon dioxide inefficiencies exist in modern wastewater networks, but uniquely identifies targeted actions to reduce inefficiencies, especially retrofitting existing WWTPs to reduce $\mathrm{CO}_{2}$ emitted and energy used in the wastewater infrastructure to make major advances towards achieving climate change reduction targets.
\end{abstract}

Keywords: wastewater, infrastructure, carbon dioxide, energy use, retrofit, resources, 


\section{Nomenclature}

$r_{X, p s}=$ primary total suspended solids removal rate $(\mathrm{g} \mathrm{VSS} / \mathrm{d})$

$\% T S S_{X, p s}=$ percent removal of suspended solids in primary clarifier

$Q_{i}=$ influent wastewater average dry weather flow $\left(\mathrm{m}^{3} / \mathrm{d}\right)$

$X_{i}=$ influent total suspended solids $\left(\mathrm{g} / \mathrm{m}^{3}\right)$

$r_{S, p c}=$ primary $\mathrm{BOD}_{5}$ removal rate $\left(\mathrm{g} \mathrm{BOD}_{5} / \mathrm{d}\right)$

$\% B O D_{S, p c}=$ percent removal of BOD in primary clarifier

$S_{i}=$ influent $\mathrm{BOD}_{5}\left(\mathrm{~g} / \mathrm{m}^{3}\right)$

$P_{x, V S S}=$ net waste activated sludge produced each day, measured in terms of total suspended solids, $\mathrm{kg} / \mathrm{d}$

$X_{o, i}=$ non biodegradable VSS in influent

$r_{O_{2}}=$ oxygen removal rate $\left(\mathrm{g} \mathrm{O}_{2} / \mathrm{d}\right)$

$f=$ conversion factor to convert $\mathrm{BOD}_{5}$ to $\mathrm{BODu}$

$r_{S, B}=$ biological $\mathrm{BOD}_{5}$ removal rate $\left(\mathrm{g} \mathrm{BOD}_{5} / \mathrm{d}\right)$

$Y=$ mean cell coefficient

$\% R e m v_{A n}=$ fraction of total solids that is converted, a $50 \%$ conversion was assumed as suggested by Northumbria Water Ltd.

$V S_{\text {deg.An }}=$ solids that are reduced due to anaerobic digestion $(\mathrm{g} /$ day $)$

Methane $_{\text {prod }}=$ volume of anaerobic digestion biogas produced $\left(\mathrm{m}^{3} / \mathrm{d}\right)$

$G P R=$ anaerobic methane production rate $\left(\mathrm{m}^{3}\right.$ gas/ tonne of dry solids fed $)$

$M_{X w w, t}=$ Amount of wet solids that require transport ( $\mathrm{t} /$ year $)$

$\% x=$ Percentage of dry solids

$W_{\text {load }}=$ Weight of sludge taken per load ( $\mathrm{t} /$ load), a mean value of $11.2 \mathrm{t} /$ load was used 


\section{Introduction}

There is a global need to reduce the amount of energy used and Greenhouse Gases (GHG) emitted, including Carbon Dioxide $\left(\mathrm{CO}_{2}\right)$, in all human activities. The European Parliament has committed member states to reduce GHG emissions and energy consumption by at least 20\% between 1990 and 2020, and national action is occuring across Europe [1]. In England, a further commitment is to reduce $\mathrm{CO}_{2}$ emissions by $80 \%$ by 2050 (1990 baseline) through the Climate Change Act [2]. However, achieving such ambitious targets will require substantial changes in delivering public services, including provision of drinking water and wastewater treatment systems and its associated infrastructure [3]. The challenge is that the operators are locked-in to its existing water and wastewater infrastructure, which was largely built when $\mathrm{CO}_{2}$ emissions and energy use was not a major consideration. Therefore, chronic carbon and energy inefficiencies exist across water and wastewater networks, which require dramatic modifications to achieve a sustainable future. There is an urgent need for WWTP operators across the world to identify new ways to get the most value out of its existing infrastructures and this study provides a rigorous and novel way of justifying new investments for retrofitting new treatment technologies to the wastewater network. This paper demonstrates the energy and carbon dioxide inefficiencies that exist in modern wastewater networks, and provides novel actions and retrofitting options to reduce such inefficiencies.

Although minimising $\mathrm{CO}_{2}$ emitted and energy used have become operating considerations in the water industry [4], there is still limited real data to guide targeted infrastructural changes to achieve the emission reduction goals. This is partly because alternate treatment technologies are not fully developed, and actual $\mathrm{CO}_{2}$ emission and energy use data from fullscale operations have been unavailable. In fact, inadequate and dependable data on the water and wastewater infrastructure is recognised as a major knowledge gap [5, 6]; making it very hard to baseline emissions and energy use in current networks, which in turn, makes informed strategic decisions difficult. This knowledge gap is closing [7, 8], but the scale of mandated $\mathrm{CO}_{2}$ and energy reductions within the urban water infrastructure is massive and more is needed. Indeed a recent review showed that most benchmarking methods are of diagnostic nature and do not provide improvement strategies to increase wastewater treatment plant (WWTP) efficiencies [9].

A case study utilising a system wide LCA, that is to include the construction and operation phase of the wastewater system, compared centralised and decentralised wastewater systems 
in California [10]. They found that decentralised system requires 37 GJ of primary energy for every million litres of wastewater treated, compared with $6.8 \mathrm{GJ}$ with the centralised system. They attributed the significant difference mainly to the operational electricity, which was seven times higher for the decentralised system [10].

Comparing the electricity intensity and associated carbon emissions of WWTPs in USA, Germany, China, and South Africa, Wang et al. [11] showed that energy self-sufficiency is feasible for wastewater treatment if a combination of increased energy efficiency and energy harvesting from the wastewater is installed. A recent review of energy use and energy recovery in the wastewater treatment sector has shown that most energy self-sufficient WWTPs are using biogas from the anaerobic digestion of sludge for digester heating and electricity generation [12].

Drinking and wastewater infrastructures are intrinsically connected, but they differ in terms of how energy is used and where $\mathrm{CO}_{2}$ is produced $[3,6]$ as the wastewater industry can use two to six times more energy than the drinking water industry [13]. Wastewater infrastructures are more varied, ranging from small decentralised collection and treatment options, which discharge to large collection networks spanning whole cities or regions, to the local discharge to sensitive receiving waters. Further, wastewater treatment technologies range from activated sludge (AS) to biofilters $(\mathrm{BF})$ to tertiary technologies (e.g., for nitrogen $(\mathrm{N})$ and-or phosphorus $(\mathrm{P})$ removal) to algal-based systems, which can potentially reduce $\mathrm{CO}_{2}$ emissions $[14,15]$.

The best combination to reduce energy consumption needs to be determined based on the local conditions [11]. The chosen technology is usually an industrial and commercial decision, and not a political or regional planning one, as decision depends on effluent load, plant age, installation and running costs, and other factors. Given such diversity, it is not surprising energy use and $\mathrm{CO}_{2}$ emissions vary widely among different wastewater treatment options [9, 16-18]. Historically, chosen treatment technologies have primarily focused on achieving effluent quality targets, which has biased decisions processes, such as AS, which readily achieves high organic removal rates, but also uses much more energy.

The question is how to satisfy future $\mathrm{CO}_{2}$ emission and energy mandates in a world where existing infrastructure was not developed to minimise energy use or $\mathrm{CO}_{2}$ emissions. 
Wastewater treatment plants (WWTPs) have a typical life span of $\sim 50$ years for concrete structures and sewer lines are often designed for 80-100 years use [19]. Therefore, building new low-energy WWTPs and-or sewers is not a practical option in many cases, and it may be more feasible to retrofit existing WWTPs with improved treatment technologies. For example, most large WWTPs in the UK use AS for their secondary treatment step, which is energy-consuming due to active aeration in carbon degradation. Indeed a recent case study in Italy found that $50 \%$ of the energy is used from aeration in oxidation tanks [20]. However, if one could reduce carbon inputs to the existing AS plants, using lower pre-treatment options (e.g., BF), similar effluent quality could be retained using less energy [15]; an approach used in industrial waste treatment [21]. Retrofitting requires capital investment, but if such investment is strategic and considers economies of scale (i.e., retrofitting is most valuable in large WWTPs), considerable rewards could be reaped by reducing operational energy costs in a future where energy will be more expensive and penalties for not meeting emission targets are more costly [22]. For such change to occur, water companies and related stakeholders must have data on which to make investment decisions. Several studies have been based on hypothetical design parameters and/or data from one or two selected WWTPs to calculate energy and $\mathrm{CO}_{2}$ emissions loads $[8,16,23-26]$. Some studies consider a range of WWTPs (e.g. India, West England [26], Spain [27]) and recently, reviews of previous energy and LCA WWTPs studies have emerged $[12,18]$.

This research has worked with a major wastewater infrastructure provider Northumbrian Water Ltd (NWL) who provided actual operating data to optimise its wastewater treatment strategies. The analysis included 87 WWTPs and 196 pumping stations across four counties in NE England to quantify energy use and $\mathrm{CO}_{2}$ emitted from actual operations across the network. Specifically, NWL data approximated baseline energy and $\mathrm{CO}_{2}$ conditions, and we then estimate the impact of different retrofit options (e.g., BF vs AS) and alternate technologies to guide decision-making if the implementation is supporting operational and global targets.

International benchmarking can be used to increase understanding of energy efficiency in WWTPs. However energy generation, as well WWTP technology and target effluent quality [12] differs across countries. Thus it is logical that the best combination to reduce energy consumption needs to be determined based on the local conditions [11]. This research is addressing several novelty issues with respect to the previously cited studies. It is the first 
detailed study that includes not only the treatment technologies at the WWTP but also includes the water pumping stations and by doing so being representative of the WWTP network across the NE region. It suggests changes to the current process by introducing and quantifying the $\mathrm{CO}_{2}$ emission reduction potential for novel technologies that can be retrofitted to the existing infrastructure. The research has transformational impact as retrofitting technologies are currently being considered by WWTP operators across the world, who are looking for new ways to get the most value out of its existing WWTP infrastructures. The methods to quantify and project the $\mathrm{CO}_{2}$ emissions of the WWTP network can be transferred to other studies, regions and countries. By providing a detailed inventory and calculation procedure of an existing network this study demonstrates for the first time the real life implications of retrofitting WWTP to a network. We provide evidence how to gain benefits from retrofitting and turn current lock-ins into opportunities in order to achieve $\mathrm{CO}_{2}$ reduction targets and confirm some of the theoretical arguments that have been made for years $[4,11]$.

\section{Methodology}

\subsection{Wastewater infrastructure energy and $\mathrm{CO}_{2}$ emissions assessment}

This study quantified energy use and $\mathrm{CO}_{2}$ emissions across a regional wastewater network (i.e., NWL) to examine the value of retrofitting existing WWTPs. It determines the baseline energy and $\mathrm{CO}_{2}$ flows in the network (in 2010) and performs a life-cycle inventory for this purpose. The NWL network was bounded according to Figure 1, which is structured in line with ISO 14040 (BS EN ISO 14040, 2006) and ISO 14044 (BS EN ISO 14044, 2006), although uncertainties common to these methods were considered [10, 28, 29].

Using this baseline, energy inputs/outputs due to transportation, pumping, and wastewater treatment activities were tallied from NWL data, and outputs were estimated for $\mathrm{CO}_{2}$ emissions to air, residual biosolids placed onto land, and liquid effluents discharged to receiving waters. Previous work has shown most long-term total energy and $\mathrm{CO}_{2}$ emissions in WWTPs occur during routine operations, especially from the biological treatment step [30]. However, construction material can be $33 \%$ to $46 \%$ of total energy when considering a 10 year lifetime for steel or iron [26]. Therefore, the life-cycle inventory developed centred on the operation of biotreatment processes most common within the NWL network (i.e., AS or BF). Data from 87 WWTPs (16 AS and 71 BF plants) and 196 pump stations were compiled 
for the analysis. The system boundary included biological secondary processes (Figure 1) which will produce high $\mathrm{CO}_{2}$ emissions when operated at effective sludge retention times, hence greenhouse gas (GHG) emissions were not considered in this study. Other GHG emissions such as nitrous oxide and methane would be mainly derived from nutrient removal processes or biosolids stabilisation not considered in the system boundary (Figure 1); and methane produced during $\mathrm{AD}$ would be combusted to $\mathrm{CO}_{2}$. Future studies should consider all processes (e.g. tertiary treatment) and inefficiencies in the system in order to refine inventory results.

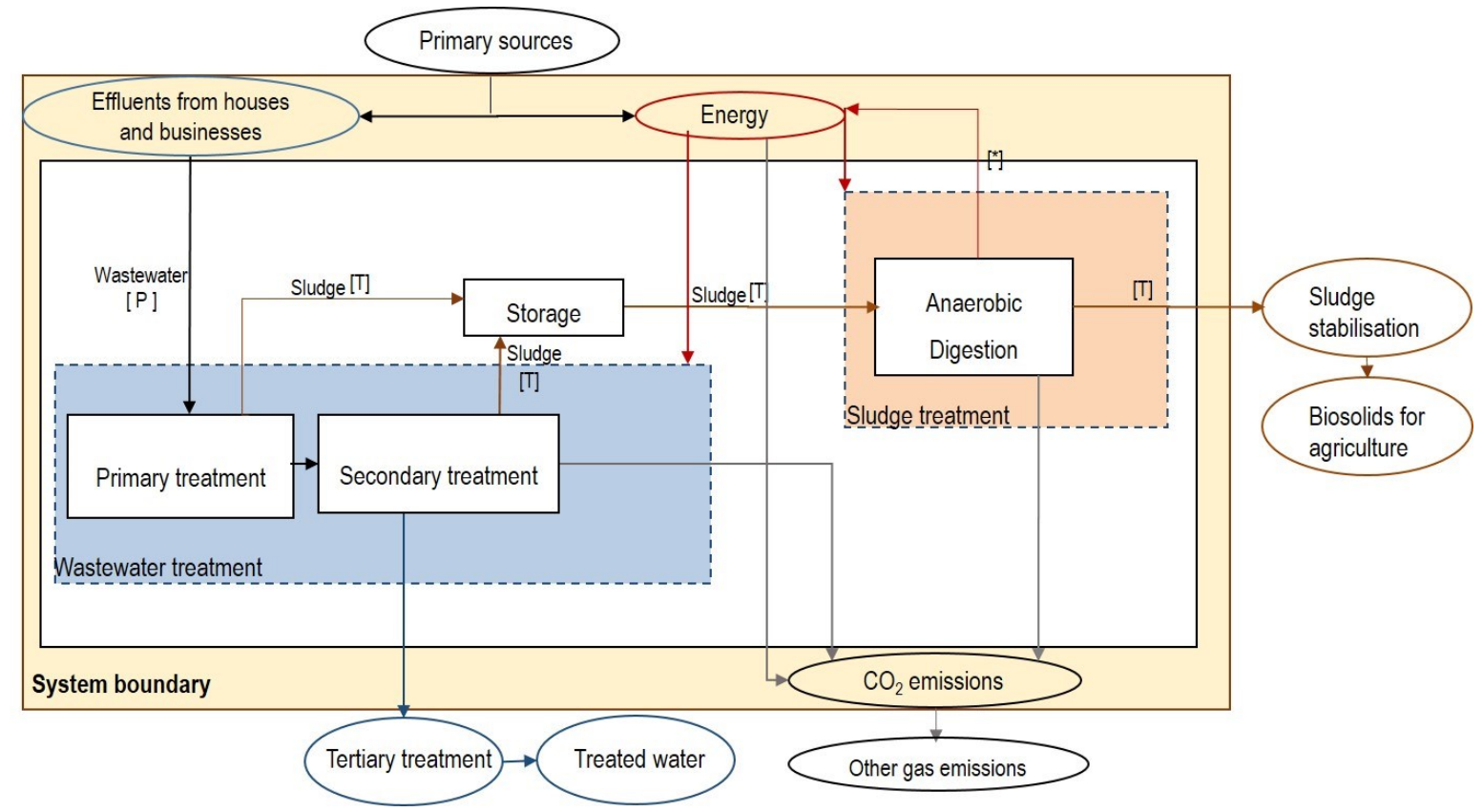

Figure 1: System boundary and flow model used to compile the wastewater and sludge inventory during operation. All processes considered in the wastewater infrastructure are included inside the white square. $[\mathrm{P}]$ stands for pumping, $[\mathrm{T}]$ stands for transportation, $[*]$ Energy produced from combusting biogas. Wastewater treatment does not consider nutrient removal.

The functional unit for comparisons among energy and $\mathrm{CO}_{2}$ flows was "per cubic meter of treated wastewater", which is consistent with standards set by European Council Directive 91/271/EEC concerning wastewater treatment. As such, all transport, pumping and treatment contributions were quantified in terms of the functional unit. Treatment plants provided total equivalent population and dry weather daily flowrates which were converted to a BOD load considering, an average daily flow $60 \mathrm{~g}$ of BOD per person per day. Specifically, energy, 
sludge and $\mathrm{CO}_{2}$ used or emitted, respectively, were tallied or calculated from NWL data or literature values and are reported here in terms of wastewater volume treated.

All WWTPs used in this assessment are managed by NWL (Figure 2). In most cases, the WWTPs receive mainly domestic wastewater, although some WWTPs also receive industrial wastewaters transported via combined sewage collection networks. Further, each WWTP treats and discharges liquid effluents locally, whereas sludge from all WWTPs are dewatered locally and transported to two central Anaerobic Digestion (AD) facilities within the region (see Figure 2). In summary, energy use/outputs and $\mathrm{CO}_{2}$ emissions include those from WWTPs themselves, wastewater pumping in the network, sludge transport to central facilities, and outputs at the AD sites.

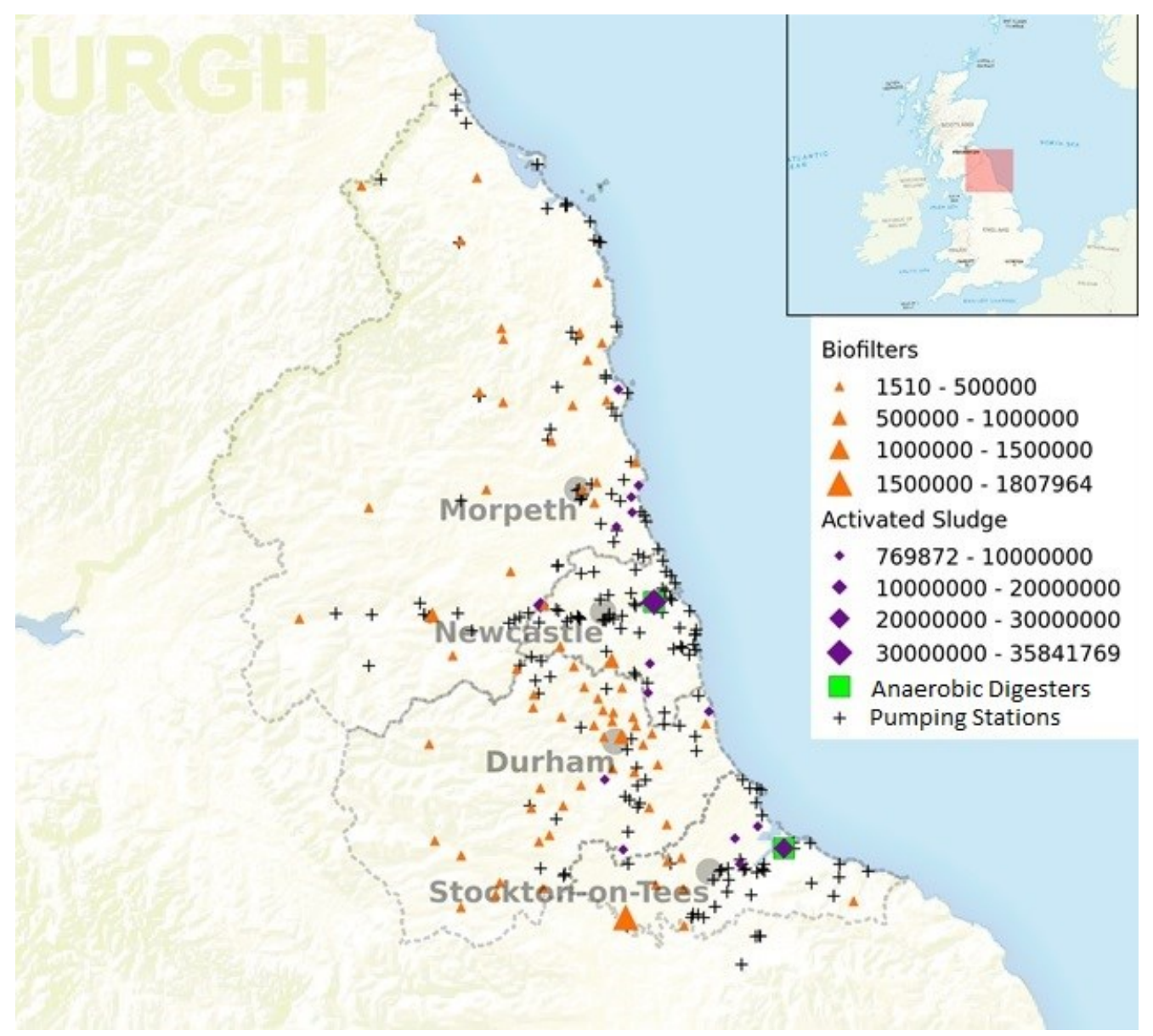

Figure 2: Wastewater treatment network in the North East region. The map shows the location of the waste treatment plants, the pump stations and the two AD facilities. Triangles correspond to biofilters whilst diamonds correspond to activated sludge, symbols are sized according to their total energy use in $\mathrm{kWh}$ for 2010 . The region is divided into four counties 
(up-down direction): Northumberland (located city on map: Morpeth), Tyne and Wear (Newcastle), Durham (Durham) and Tees Valley (Stockton-on-Tees).

\subsubsection{Wastewater treatment plants and pumping stations}

Energy use data for WWTPs and pumping stations were provided by NWL for 2010. These data are directly reported here as "energy used". However, $\mathrm{CO}_{2}$ emissions are not typically recorded; therefore, $\mathrm{CO}_{2}$ emissions were estimated based on measured energy use data, organic loading rates, and known stoichiometric relationships between organic matter degradation, $\mathrm{CO}_{2}$ and biomass production. $\mathrm{CO}_{2}$ emissions from energy use were estimated according to the emissions produced from the fuel mix used by NWL's energy supplier (i.e., $541 \mathrm{~g} \mathrm{CO}_{2} / \mathrm{kWh}$ ) [31]. This ratio also was used to obtain $\mathrm{CO}_{2}$ emissions for pumping stations. Wastewater treatment itself and sludge $\mathrm{AD}$ also included $\mathrm{CO}_{2}$ production from their biological processes. These were calculated by obtaining the $\mathrm{CO}_{2}$ production from known biological oxygen demands (as BOD; extrapolated from COD) due to organic matter in wastewater entering each plant (provided by NWL) using the method reported by Monteith, Sahely [32]. This method is based on process stoichiometry and extraneous $\mathrm{CO}_{2}$ production from endogenous respiration. $\mathrm{CO}_{2}$ outputs included those from the core biological process (e.g., AS or BF) and from sludge processing, which assumed $30 / 70 \% \mathrm{CO}_{2} / \mathrm{CH}_{4}$ mixed biogas.

WWTPs using conventional Activated Sludge (AS) treatment: Typical the AS plants of NWL consist of pre-screening, primary settling, biological treatment, secondary clarification and sludge dewatering. The wastewater first flows through preliminary processes, including bar and conveyor rag screens, to remove larger solid debris. Based on NWL data, these processes produce sludge for transport that require eight vehicle loads per year per WWTP. After wastewater screening, it passes through grit chambers where small inert solids are removed, which across the network, produces about two transport-loads per year per WWTP. The wastewater then enters primary settling tanks, which are designed to remove the majority of settleable solids, which for our analysis, was estimated according to assumptions shown in Table 1. The remaining (primarily) soluble organic matter is biodegraded in the treatment units. These units are often operated in parallel "treatment trains" to permit operationally flexibility, but also to sustain and control optimal retention times for effective waste treatment. Sludge generated during secondary treatment is removed in secondary clarifiers, and the liquid supernatant is discharged to the environment in most cases. Actual sludge 
production in secondary treatment was calculated using parameters shown in Table 1 and standard relationships summarised in Metcalf \& Eddy., Tchobanoglous [33].

Table 1: Assumed wastewater treatment parameters used in energy and performance calculations.

\begin{tabular}{|c|c|c|c|c|}
\hline Unit Operation & Parameter & Value & Units & Reference \\
\hline \multirow{3}{*}{$\begin{array}{c}\text { Primary } \\
\text { Sedimentation }\end{array}$} & $\mathrm{BOD}_{5}$ removal & 26 & $\%$ & [33] \\
\hline & TSS removal & 50 & $\%$ & [33] \\
\hline & TSS & 0.21 & $\mathrm{~g} / \mathrm{L}$ & [33] \\
\hline \multirow{5}{*}{$\begin{array}{l}\text { Biofiltration } \\
\text { Units }\end{array}$} & TSS/VSS & 1.18 & ratio & [33] \\
\hline & Mean cell yield, Y & 0.28 & $\begin{array}{l}\mathrm{g} \mathrm{VSS} / \mathrm{g} \\
\mathrm{bsCOD}\end{array}$ & [34] \\
\hline & Decay coefficient, $\mathrm{k}_{\mathrm{d}}$ & 0.01 & L/day & {$[34]$} \\
\hline & Sludge retention time, SRT & 18 & days & From NWL \\
\hline & Biomass in cell debris, $\mathrm{f}_{\mathrm{d}}$ & 0.10 & $\begin{array}{c}\mathrm{g} \mathrm{VSS} / \mathrm{g} \\
\mathrm{VSS}\end{array}$ & {$[33]$} \\
\hline \multirow{4}{*}{$\begin{array}{c}\text { Aerobic } \\
\text { Activated } \\
\text { Sludge }\end{array}$} & Mean cell yield, Y & 0.60 & $\begin{array}{l}\text { g VSS/g } \\
\text { bsCOD }\end{array}$ & {$[33]$} \\
\hline & Decay coefficient, $\mathrm{k}_{\mathrm{d}}$ & 0.06 & L/day & {$[33]$} \\
\hline & Sludge retention time, SRT & 10 & days & From NWL \\
\hline & Biomass in cell debris, $f_{d}$ & 0.15 & $\begin{array}{c}\mathrm{g} \mathrm{VSS} / \mathrm{g} \\
\mathrm{VSS}\end{array}$ & [33] \\
\hline
\end{tabular}

WWTPs using Biotrickling Filters (BF): BF plants include the same basic unit operations as AS plants, except fixed-film bioreactors are substituted for the AS units. It should be noted that a variety of BFs are used across the NWL network, but we have homogenised the definition for the sake of simplicity, which is a reasonable assumption, given the mechanistic similarity and diversity of BF plants across the network. As background, BFs in the NWL network usually comprise of packed solid media made from blast furnace materials or commercial plastic, both of which serve as a physical support for attached bacterial growth. In this BF process, effluent after primary settling enters a column or chamber where transverse contact occurs with biofilms on the solid media. Flow is sometimes gravity-based, but more often is under pressure (requiring pumping), frequently driving sprinkling arms that disperse the wastewater across the top surface of the BF. Treatment occurs as the waste trickles through the BF and effluents are typically passed to clarifiers like AS. However, the amount of sludge produced by BF units tends to be lower than AS. Estimates of sludge 
produced in BFs were made using assumed parameters shown in Table 1 as reported by Kong and Yang [34].

\subsubsection{Sludge treatment and transport}

Both, AS and BF are common across the NWL network, and how much sludge is produced differs according to technology and controlling parameters (Table 1). BF units tend produce less sludge because in-reactor solids retention times is often longer as the organisms are attached on surfaces, which extends retention time and also increases endogenous decay. In contrast, net biomass yields tend to be higher in AS units because of higher rates of metabolic activity due to active aeration and also lower endogenous decay.

Regardless plant type; most NWL WWTPs do not process their solids locally. Rather, local centrifugation units are used concentrate sludge on-site, which is then transported to the central AD units. Specifically, concentrated sludge is stored in open-top silos and carried as a wet slurry by six- and eight-wheeler diesel tank trucks to AD facilities in Howdon (within Newcastle upon Tyne) and Bran Sands (near Middlesbrough, Tees Valley) (Figure 2). For the purpose of sludge transport calculations, we assumed WWTPs in Tyne \& Wear and Northumberland send their solids to the Howdon, whereas Tees Valley and Durham send their sludge to Bran Sands. Therefore, Arc-GIS software was used to map mean transport paths related to the spatial arrangement of WWTPs and locations of the two AD units as central nodes. Vehicle data were available (i.e., 8-wheel [9.3 t/load] and 6-wheel vehicles [13 t/load] for sludge transport) and Arc GIS was used to estimate the mean vehicle travel-miles per region.

Once concentrated sludge arrives at the AD sites, the sludge is thermally hydrolysed using high-pressure steam using the Cambi process and fed into the actual digesters, which digest the solids into combustible biogas (and "insert" solid residuals), which is used to produce electricity that is sold to the energy grid. AD solid residuals (about 40\% dry weight; 42) are transported by tank truck to agricultural sites across the region for used as a soil conditioner and nitrogen fertilizer. Field loading of the AD residuals is defined by the soil type and nitrate content at each site.

Given the agricultural fields are scattered across the region, it was assumed (for transport estimates) that each region received similar proportions of AD biosolids to WWTP sludge produced. Therefore, the distance travelled per load was assumed to be the same as that used 
for sludge transport. However, spreading and transport was performed the smallest wheelers; i.e., 8-wheel and 9.3 t/load. All transport and $\mathrm{CO}_{2}$ energy estimates assume diesel fuel and 6.5 miles per Imperial gallon, which produce $2.7 \mathrm{~g} \mathrm{CO}_{2} / \mathrm{m}^{3}$ and use $9.7 \mathrm{Wh} / \mathrm{m}^{3}$ diesel consumed [35].

Data on energy gains and use, and $\mathrm{CO}_{2}$ emissions associated with sludge processes were available from Howden and Bran Sand operations; i.e., $\mathrm{CO}_{2}$ produced by the $\mathrm{AD}$ units in biogas production (30\%) and methane (70\%) produced for combustion and heat generation. Heat generators were assumed to produce $0.2 \mathrm{kgCO}_{2} / \mathrm{KWh}_{[36}$

\subsection{Wastewater infrastructure energy and $\mathrm{CO}_{2}$ model calculator}

Equations used to estimate sludge and $\mathrm{CO}_{2}$ production were input to a calculator model (in Microsoft Excel ${ }^{\circledR} 2010$ ) along with energy data provided. The model ran by sequentially solving a series of equations (provided in SI) according to unit operations in the WWTPs: 1) TSS and BOD removed in the first clarifier; 2) total sludge produced and BOD removed in the aeration reactor; 3) $\mathrm{CO}_{2}$ produced in the aeration reactor from organic matter conversion and endogenous respiration; and 4) $\mathrm{CO}_{2}$ produced from energy used. An additional excel sheet was used to obtain the energy used and $\mathrm{CO}_{2}$ emissions from sludge and biosolids transportation. Results were used to perform quantitative comparisons among key activities within the network (e.g., transport, waste treatment). It should be noted there is limited precedence to this study; therefore the goal was to not overly complicate the analysis, but more to develop overarching impressions to guide strategic decisions rather that provide detailed predictions. As such, limitations of the model derive from assumptions made to calculate $\mathrm{CO}_{2}$ emitted and sludge produced, as energy used was a measured dataset.

However, all assumptions, input data, and calculations were validated through cross-checking with NWL experts and comparisons with peer-reviewed and 'grey' literature. Further, to ensure model predictions were not too rigid, sensitivity analysis was performed on outputs by changing selected input data; particularly the influence of varying organic load as biological oxygen demand (BOD).

\subsubsection{Calculations for wastewater treatment plants}

Data obtained from the 87 treatment plants was used to calculate, in theory, the amount of $\mathrm{CO}_{2}$ and sludge emissions. Energy used for the treatment plants was obtained using monthly data readings. All calculations were based on the amount of organic matter as BOD 
(excluding non-residents) entering each plant per day. This was obtained by multiplying the reported BOD concentration for each plant by the total dry weather flow (not considering rainfall); both values were obtained by NWL.

The amount of total solids produced as sludge was calculated considering primary sedimentation and biological treatment. The amount of solids separated in the primary settlers was determined using Equation 1 (Table 2). As TSS values at the inlet of the treatment process were not available for all treatment plants a concentration of $210 \mathrm{mg} / \mathrm{L}$ was assumed, from which $85 \%$ were assumed to be volatile (VSS). From the total VSS $15 \%$ were considered non-biodegradable and 5\% inert organics. The removal of total suspended solids from organic matter helps decreasing the BOD. In order to estimate the amount of BOD removed, Equation 2 was used. After the primary clarifier, wastewater proceeds to biological treatment. At this stage some the organic matter in wastewater is converted to sludge (new biomass) or $\mathrm{CO}_{2}$. To determine the amount of organic matter converted to biomass, the mass balance used by [33] was found appropriate and can be written as shown in equation 3 . The total amount of suspended solids removed was obtained by adding the proportion of total biomass not considered in the equation above as shown in [33].

Following Monteith et al. [32] $\mathrm{CO}_{2}$ emissions were derived from the carbon not incorporated into biomass using the reaction mechanism for the oxidation of organic matter $\left(\mathrm{C}_{10} \mathrm{H}_{19} \mathrm{O}_{3} \mathrm{~N}\right)$ to $\mathrm{CO}_{2}$. According to this reaction the conversion ratio was $1.1 \mathrm{~kg} \mathrm{CO}_{2} / \mathrm{kg} \mathrm{O}_{2}$ (Equation 4). To obtain the oxygen consumed for growth Equation 5 was used; here a ratio of 1.42 is multiplied by the mean cell coefficient $(\mathrm{Y})$ and subtracted to the overall oxygen requirement. This ratio was derived from the reversal of the reaction mechanism, where oxygen is produced, shown in Equation 4. An additional contributor to $\mathrm{CO}_{2}$ emissions was derived from endogenous respiration. The process of endogenous respiration is shown in Equation 6 where a fraction of the organic matter produced $\left(\mathrm{C}_{5} \mathrm{H}_{7} \mathrm{O}_{2} \mathrm{~N}\right)$ is further oxidised. In this reaction we can see that 5 moles of $\mathrm{CO}_{2}$ are produced per mole of biomass. Conversion ratios of 0.35 and $1.17 \mathrm{Kg} \mathrm{CO}_{2} / \mathrm{Kg}$ of biomass were obtained for bio-filter and anaerobic sludge, respectively using Equation 7. Carbon dioxide emissions produced from energy consumption were calculated using the fuel mix for energy production used by Northumbrian Water's energy supplier. According to these $\mathrm{CO}_{2}$ emissions of $541 \mathrm{~g} \mathrm{CO}_{2} / \mathrm{kWh}$ were obtained. 
Table 2: Equations used for wastewater treatment calculations

\begin{tabular}{|c|c|c|}
\hline Equation \# & Concept & Model equation \\
\hline 1 & $\begin{array}{l}\text { Primary total suspended } \\
\text { solids removal rate }\end{array}$ & $r_{X, p c}=\% T S S_{X, p s} Q_{i} X_{i}$ \\
\hline 2 & Primary BOD removal rate & $r_{S, p c}=\% B O D_{S, p c} Q_{i} S_{i}$ \\
\hline 3 & $\begin{array}{l}\text { Net waste activated sludge } \\
\text { produced per day }\end{array}$ & $\begin{array}{c}P_{x, V S S}=\frac{Q_{i} Y\left(S_{i}-S\right)}{1+(k d) S R T}+\frac{\left(f_{d}\right)\left(k_{d}\right) Y Q_{i}\left(S_{i}-S\right) S R T}{1+(k d) S R T} \\
+Q X_{o, i}\end{array}$ \\
\hline 4 & $\begin{array}{l}\text { Carbon emissions from } \\
\text { biomass }\end{array}$ & $\mathrm{C}_{10} \mathrm{H}_{19} \mathrm{O}_{3} \mathrm{~N}+25 \mathrm{O}_{2} \rightarrow 20 \mathrm{CO}_{2}+16 \mathrm{H}_{2} \mathrm{O}+2 \mathrm{NH}_{3}$ \\
\hline 5 & Oxygen removal rate & $r_{o_{2}}=r_{S, B}\left(\frac{1}{f}-1.42 Y\right)$ \\
\hline 6 & $\begin{array}{l}\text { Carbon dioxide from } \\
\text { endogenous respiration }\end{array}$ & $\mathrm{C}_{5} \mathrm{H}_{7} \mathrm{O}_{2} \mathrm{~N}+5 \mathrm{O}_{2} \rightarrow 5 \mathrm{CO}_{2}+2 \mathrm{H}_{2} \mathrm{O}+\mathrm{NH}_{3}$ \\
\hline 7 & $\begin{array}{l}\text { Conversion ratios of } \\
\text { biomass }\end{array}$ & $\frac{\mathrm{kgCO}_{2}}{\mathrm{kgbiomass}}=\operatorname{SRT}(\mathrm{kd})\left(5 \times \frac{44}{113}\right)$ \\
\hline
\end{tabular}

\subsubsection{Calculations for sludge treatment and transport}

The total amount of dry solids (sludge) produced $\left(M_{X w}\right)$ was obtained by adding the amount of solids removed during primary settlement and biological treatment, according to Equation 8 (Table 3 ). Total solids produced are treated by anaerobic digestion. In this process a fraction of organic matter in the dry solids is transformed to methane and carbon dioxide. The amount of dry solids converted was determined using Equation 9. The volume of biogas produced was related to the amount of dry solids fed according to Equation 10. It was considered that $274 \mathrm{~m}^{3}$ methane/ tonne of dry solids fed were produced according to values indicated in the literature [37]. The energy produced was transformed to $\mathrm{kWh}$ assuming a process conversion rate of $60 \%$ and a ratio of $10.83 \mathrm{kWh} / \mathrm{m}^{3}$ of methane. The energy used by the $\mathrm{AD}$ was subtracted in order to obtain the net energy produced by anaerobic digestion (considered to be $35 \%$ of the energy produced according to real data).

As sludge is transported wet, the total dry sludge obtained was converted into wet sludge considering that dry solids only accounted for $15 \%$ of the overall biomass. Northumbrian Water stated that the sludge collected in treatment plants has between $90 \%-80 \%$ of liquids by 
weight. This is because centrifugation is conducted in most treatment plants to decrease the water content of sludge. To obtain the overall wet sludge to be transported for treatment the amount of sludge produced in the treatment plants, where AD digesters are located, was subtracted as per Equation 11. In order to conduct this analysis the "Mean Center Geographical Distribution" function was selected within the ArcTool box options in Arc GIS 10.0. In this function sludge production was selected as the "weight field" and type of region as the "case field". Once a weighted geographical centre was obtained, a postcode was given that corresponded to its spatial location. Then, the distance travelled to the corresponding AD plant was obtained. Northumbrian Water uses 8 wheeler $(9.3$ t/load) and 6 wheeler vehicles $(13 \mathrm{t} /$ load) to transport sludge from treatment facilities to the AD plant. The number of miles travelled per region was estimated using Equation 12.

Table 3: Equations used for sludge treatment and transport calculations

\begin{tabular}{|clc|}
\hline Equation \# & \multicolumn{1}{c|}{ Concept } & Model equation \\
\hline 8 & $\begin{array}{l}\text { Amount of dry solids } \\
\text { produced }\end{array}$ & $M_{X w}=r_{X, p c}+P_{X, T S S}$ \\
9 & $\begin{array}{l}\text { Amount of dry solids } \\
\text { converted } \\
\text { Volume of anaerobic } \\
\text { digestion biogas produced }\end{array}$ & $V S_{d e g . A n}=\% \operatorname{Remv}_{A n} M_{X w}$ \\
10 & Amount of wet solids & Methane $_{\text {prod }}=\operatorname{GPR}\left(M_{X w}\right)$ \\
12 & Distance travelled & $M_{X w w, t}=M_{X w}\left(\frac{1}{\% x}\right)-M_{X w o n s i t e}\left(\frac{1}{\% x}\right)$ \\
\end{tabular}

\subsection{Statistical and sensitivity analyses}

To compare differences in energy use, sludge and $\mathrm{CO}_{2}$ emissions among the four counties, data was tested for statistical normality using Minitab®. It was found that data were negatively skewed, heteroscedastic and failed the normality probability test of residuals. As the datasets consisted of a nominal variable (e.g. type of biological treatment) and a numerical variable, the non-parametric Kruskal-Wallis test was selected for sample comparisons using 95\% confidence interval. The null hypothesis considered that samples were equal, and a $p$-value reported its fractional probability. Hence $p$-values $\leq 0.05$ rejected the null hypothesis, as samples were significantly different. In line with ISO standards 14040 and 14044 various sensitivity checks were conducted by changing key input parameters and 
assumptions. Sensitivity analysis considered two limiting, low and high, input conditions for WWTPs: 1) the treatment of only $20 \%$ the real regional BOD load and 2) the treatment of $180 \%$ the real regional BOD load. This was done to further refine the model and confirm it was working in a realistic manner. Predictions from the sensitivity analysis were also used to compare future cases if root assumptions were different than the core model. The anaerobic treatment system energy and carbon emissions were only modified when using a lower BOD load as it was assumed that the additional sludge produced with a higher BOD load was untreated as no additional infrastructure was in place.

\section{Results and Discussion}

\subsection{The North East region}

NE England includes four counties (Northumberland, Durham, Tyne and Wear and Tees Valley) and has an area of 8,600 square kilometres. Based on Office of National Statistics reporting [38] the 2010 population was $2,606,000$ with a density of 300 people per $\mathrm{km}^{2}$, which was below the England average of 401, but above the UK average of 257. Population densities range from 62 in rural Northumberland to $\sim 2,640$ near Middlesbrough, which is within the urban and industrial southern part of the region (Tees Valley).

The NE region produced $\sim 10.6$ tonnes of $\mathrm{CO}_{2}$ emissions per resident in 2009 , the highest of all the English regions [38]. Table 4 shows Tees Valley and Tyne \& Wear produced the highest total $\mathrm{CO}_{2}$ emissions, which were $31 \%$ and $39 \%$, respectively, of their regional total. These two counties also used the most energy among the counties, corresponding to $\sim 72 \%$ of total energy used across the region. Among all counties, Tyne \& Wear had the greatest number of residents $(1,120,000)$, which was $46 \%$ of the population in the whole Region in 2010 [38]. Considering population and industrial differences between Tees Valley and Tyne \& Wear, it is evident that energy and $\mathrm{CO}_{2}$ emissions in Tyne \& Wear were primarily driven by population density, whereas industry driven businesses most likely contributed to the higher values in Tees Valley.

Calculations from the model showed that the NE region produced $\sim 30,700$ tonnes of dry treated sludge (Table 4), reused as soil conditioner in the agricultural sector, equivalent to $\sim 76,700$ tonnes of sludge at $60 \%$ moisture. This is similar to the value of 75,900 tonnes per year reported by Byrns, Weatley [7] for the NE Region in the same year and amounts to $2 \%$ 
of the overall sewage sludge produced in the UK, which was $1,400,000$ tonnes of sewage sludge in 2010 [39].

Table 4: Energy used and carbon dioxide produced for the North East wastewater network. Values obtained for 2010 take into account the energy, carbon dioxide and sludge offsets by anaerobic digestion.

\begin{tabular}{|lccc|}
\hline \multicolumn{1}{|c}{ Area in England } & $\begin{array}{c}\text { Energy } \\
\text { MWh }\end{array}$ & $\begin{array}{c}\mathrm{CO}_{2} \\
\text { tonnes }\end{array}$ & $\begin{array}{c}\text { Treated Sludge } \\
\text { dry tonnes }\end{array}$ \\
\hline Durham & 6,744 & 14,160 & 3,712 \\
Northumberland & 13,561 & 22,220 & 5,133 \\
Tees Valley & 25,914 & 43,333 & 10,488 \\
Tyne \& Wear & 25,156 & 51,302 & 11,337 \\
North East Region & 71,376 & 131,015 & 30,670 \\
\hline
\end{tabular}

Energy use, sludge produced and $\mathrm{CO}_{2}$ emissions for biological wastewater treatment across the network is summarised in Figure 3. For all three metrics, AS plants are located at the higher end and most BF plants in the lower end of the charts. Only two AS plants, one in Tees Valley and the other in Tyne \& Wear, were in or below the median in terms of energy consumption; no AS plant was below the median in terms of sludge production or $\mathrm{CO}_{2}$ emitted. Total energy used and $\mathrm{CO}_{2}$ emissions during biological wastewater treatment differed significantly among the four counties ( $p<0.05$; Figure 3$)$. Energy use was lowest in Durham (circa $0.15 \mathrm{kWh} / \mathrm{m}^{3}$ ) followed by Tyne \& Wear, Tees Valley and Northumberland (circa. $0.3 \mathrm{kWh} / \mathrm{m}^{3}$ ). $\mathrm{CO}_{2}$ emissions were highest in Tyne \& Wear followed by Northumberland, Tees Valley and Durham with county-means ranging from $\sim 0.23$ to $\sim 0.37$ $\mathrm{kg} \mathrm{CO}_{2} / \mathrm{m}^{3}$ wastewater treated, respectively. Conversely, total sludge production levels did not differ significantly among the counties $(p>0.05)$. 


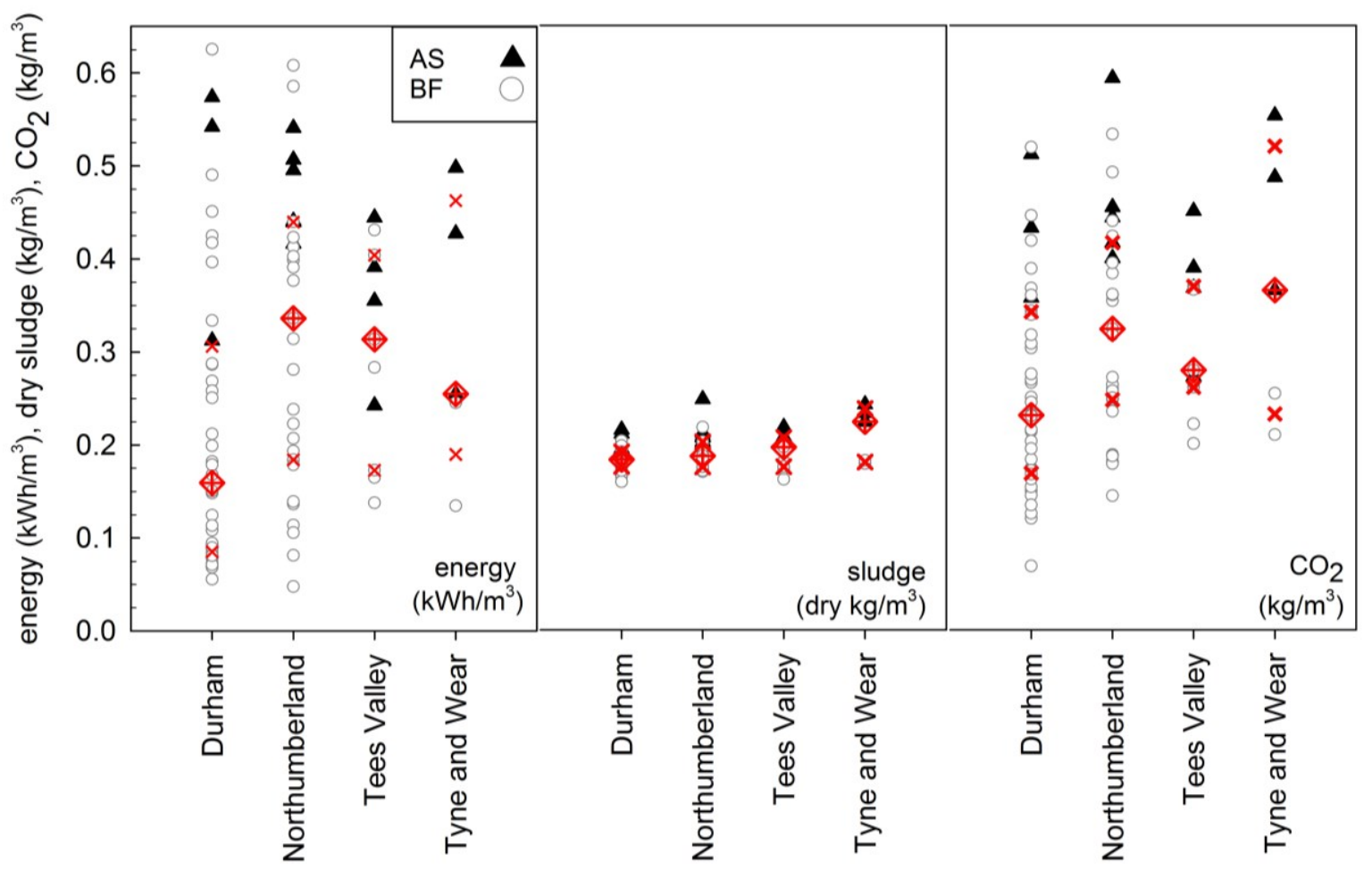

Figure 3: Statistical analysis of energy used and emissions produced from biological wastewater treatment. Red diamonds correspond to median values obtained for the region, red crosses show the $1^{\text {st }}$ or $3^{\text {rd }}$ quartiles. AS stands for Activated Sludge treatment and BF stands for biological filtration. Only WWTPs were evaluated; therefore the energy and carbon dioxide by sludge handling and pumping were not considered.

\subsection{Energy consumption and $\mathrm{CO}_{2}$ emissions in the wastewater network}

The energy use and estimated $\mathrm{CO}_{2}$ emissions produced by different components of the wastewater network across the region are summarised in Table 5. It can be seen that wastewater treatment required the highest amount of energy and produced the highest $\mathrm{CO}_{2}$ emissions, followed by pumping stations and finally sludge transportation. However, using AD to treat sewage sludge improved the overall energy balance, reducing overall energy use by about half, although $\mathrm{AD}$ only reduced net $\mathrm{CO}_{2}$ emissions by $2 \%$. This is not surprising because $\mathrm{AD}$ produces biogas (mostly $\mathrm{CO}_{2}$ and methane) as products of anaerobic degradation with $\mathrm{CO}_{2}$ largely going to atmosphere and the combustible fraction being converted to electricity plus $\mathrm{CO}_{2}$.

A comparison of the emissions produced and energy used across the wastewater network is presented in Figure 4. According to previous observations (Figure 3), this analysis took into account the fact that there was a change in the types of wastewater treatment employed in each county, which could influence energy use and $\mathrm{CO}_{2}$ emissions (Table 6). For example, a 
higher fraction of wastewater produced in Durham is treated by BF plants than by AS plants. Conversely, Tyne \& Wear treats more wastewater using AS than BF.

Table 5: Total energy used and $\mathrm{CO}_{2}$ emissions produced per system in the North East wastewater network in 2010.

\begin{tabular}{|cccccc|}
\hline & Units & Pumping Stations & Treatment & Transport & $\begin{array}{c}\text { Anaerobic } \\
\text { Digestion }\end{array}$ \\
\hline Energy use & $\mathrm{kWh} / \mathrm{m}^{3}$ & 0.11 & 0.36 & 0.013 & -0.25 \\
$\mathrm{CO}_{2}$ emissions & $\mathrm{kg} / \mathrm{m}^{3}$ & 0.06 & 0.40 & 0.005 & -0.008 \\
\hline
\end{tabular}

Table 6: Human populations and regional distribution of different WWTPs. Percentages refer to the proportional distribution of effluent in each county that uses either AS vs BF for secondary treatment.

\begin{tabular}{|cccccc|}
\hline \multirow{2}{*}{ Region } & $\begin{array}{c}\text { Populations in } \\
2010\end{array}$ & \multicolumn{2}{c}{ Activated Sludge } & \multicolumn{2}{c|}{ Biofiltration } \\
& ONS, [38] & $\%$ & number & $\%$ & number \\
\hline Durham & 511,000 & 31 & 3 & 69 & 37 \\
Northumberland & 312,000 & 84 & 6 & 16 & 25 \\
Tees Valley & 663,000 & 89 & 4 & 11 & 7 \\
Tyne \& Wear & $1,120,000$ & 96 & 3 & 4 & 2 \\
\hline
\end{tabular}




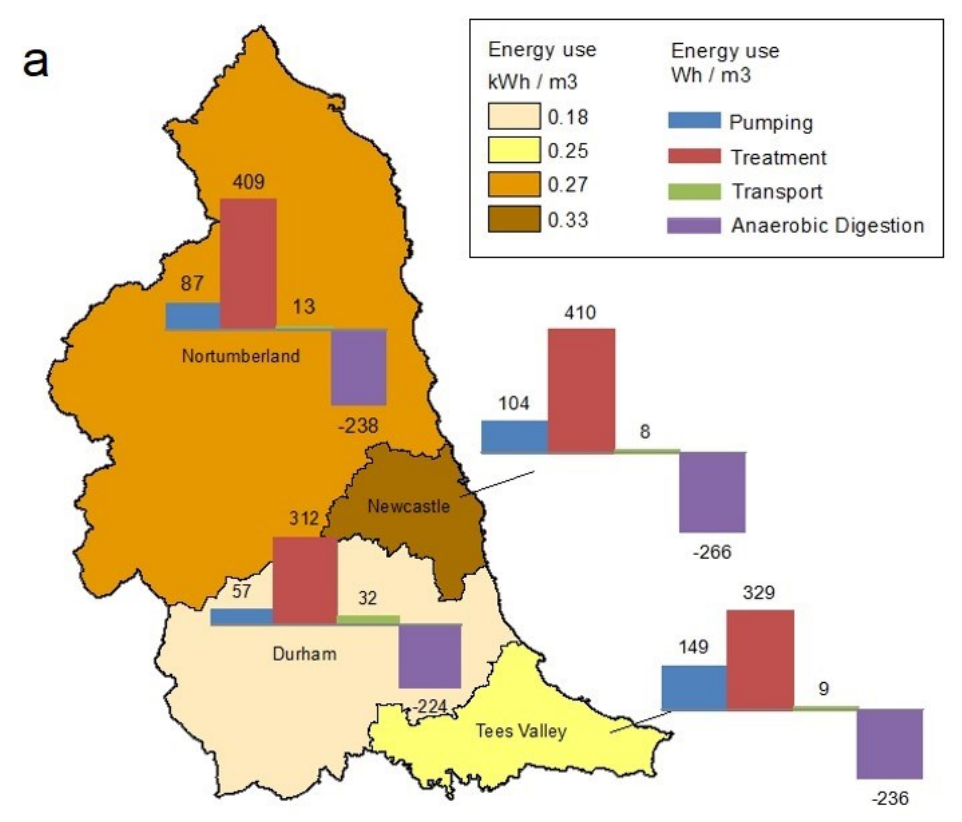

b

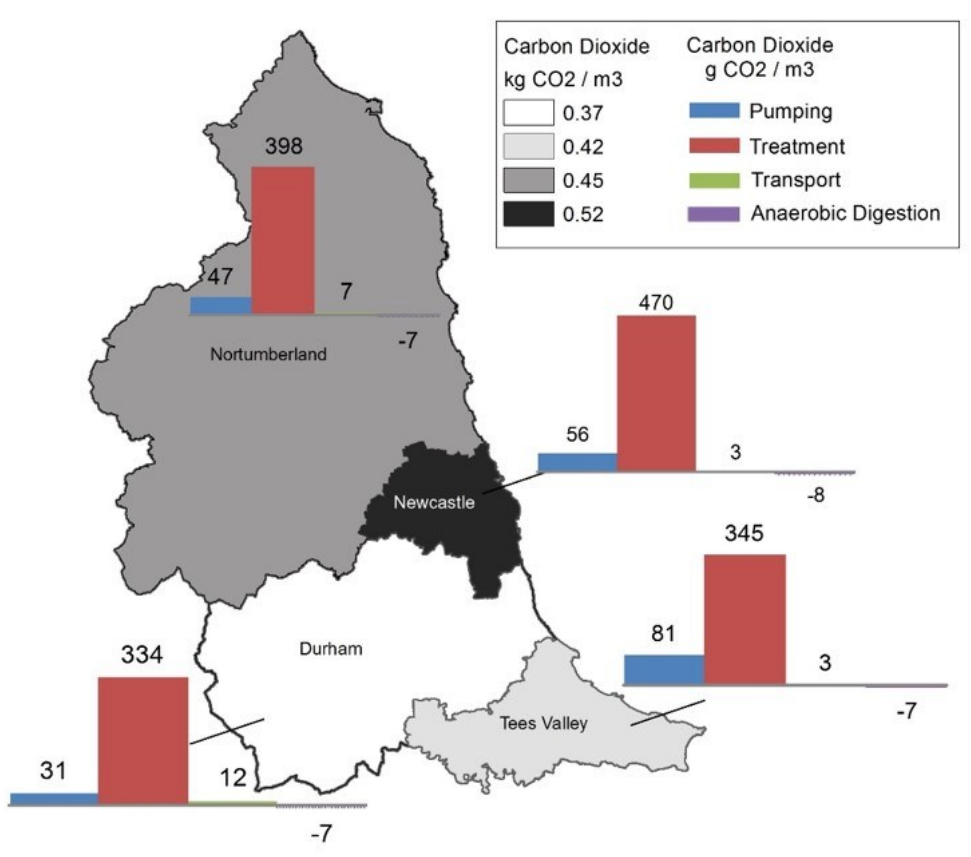

Figure 4: Energy and $\mathrm{CO}_{2}$ emissions in the North East Region wastewater network. a) Energy used for WWT per region and process in the North East. Total and process values were obtained by dividing the overall energy use per county by the overall wastewater flow treated. Energy offsets by anaerobic digestion of sludge were considered in the values obtained. b) $\mathrm{CO}_{2}$ produced for WWT per region and process in the North East. Total and process values were obtained by dividing the overall $\mathrm{CO}_{2}$ emissions per county by the overall wastewater flow treated. Energy and $\mathrm{CO}_{2}$ offsets by anaerobic digestion of sludge were considered in reported total energy use and $\mathrm{CO}_{2}$ emissions per county. 
Transportation contributed the lowest fraction of energy used in each county (Figure 4a), even in Durham, which had a high number of smaller, decentralised BF plants (Table 6); i.e., only $8 \%$ of total energy consumed for transportation. Other counties (Northumberland, Tees Valley and Tyne \& Wear) used less than 3\% of the total energy for transportation (Figure 6A). The energy used in transportation was linked to $\mathrm{CO}_{2}$ emissions; therefore Durham produced the highest $\mathrm{CO}_{2}$ fraction (4\% of overall, Figure $4 \mathrm{~b}$ ).

Energy used for pumping was, at least, one order of magnitude greater than for transportation (Figure 4a). Pumping stations in Tees Valley and Tyne \& Wear represented $31 \%$ and $20 \%$ of the total energy used, respectively, while pumping in Northumberland and Durham used $17 \%$ and $14 \%$ of the overall energy, respectively. This pattern correlated with the proportion of wastewater treated by activated sludge (Table 6); indicating that counties with centralised networks used more energy for pumping wastewater than the energy used for transportation in counties using decentralised networks. Hence, even though Tyne \& Wear used 0.23 $\mathrm{kWh} / \mathrm{m}^{3}$ for treatment, it increased to $0.64 \mathrm{kWh} / \mathrm{m}^{3}$ for the whole wastewater network (Figure $4 \mathrm{a}$, without considering $\mathrm{AD}$ offsets). $\mathrm{CO}_{2}$ emissions produced by pumping stations represented between 19\% (for Tees Valley) to 8\% (for Durham) the overall emissions for each county (Figure $4 b)$.

WWTPs were responsible for the highest fractions of energy consumed and $\mathrm{CO}_{2}$ emissions in all counties (Figure 4). Wastewater treatment accounted for $81 \%, 79 \%, 78 \%$ and $68 \%$ of overall energy used in Northumberland, Tyne \& Wear, Durham and Tees Valley, respectively. The fraction of $\mathrm{CO}_{2}$ emissions attributed to wastewater treatment were similar among the counties, the highest being for Tyne \& Wear $(89 \%)$ followed by Northumberland (88\%), Durham (87\%) and Tees Valley (86\%).

AD helped reduce the net amount of energy use in all counties, but less so for $\mathrm{CO}_{2}$ emissions (Figure 4). Using AD to treat sludge decreased the net energy used by $56 \%$ in Durham, followed by Tyne \& Wear (51\%), Tess Valley (48\%) and Northumberland (47\%). The greatest energy savings were in Durham due to lower overall energy used for treatment and pumping. A lower proportion of energy savings for Tyne \& Wear and Tees Valley were obtained by anaerobically digesting the sludge that was produced in AS treatment plants (Figure 4a and Table 1). 


\subsection{Production of emissions related to the type of wastewater treatment plant}

Wider analysis suggested that energy use and $\mathrm{CO}_{2}$ emissions by wastewater biological treatment are most important across the wastewater networks (Table 5), therefore in-plant operations were compared for AS and BF (Figures 5 and 6). Values obtained for energy used, $\mathrm{CO}_{2}$ emissions and sludge produced were significantly different $(\mathrm{p}<0.05)$ between AS and BF plants (Figure 5). AS plants used more energy (median $=0.4 \mathrm{kWh} / \mathrm{m}^{3}$ waste treated, $\mathrm{Q} 1=0.4, \mathrm{Q} 3=0.5 ;$ mean $=0.4 \pm 0.1 \mathrm{kWh} / \mathrm{m}^{3}$ ) and produced more $\mathrm{CO}_{2}$ emissions (median $=0.4$ $\mathrm{kg} / \mathrm{m}^{3}, \mathrm{Q} 1=0.4, \mathrm{Q} 3=0.5 ;$ mean $\left.=0.4 \pm 0.1 \mathrm{~kg} / \mathrm{m}^{3}\right)$ than BF plants $\left(\right.$ median $=0.2 \mathrm{kWh} / \mathrm{m}^{3}$, $\mathrm{Q} 1=0.1, \mathrm{Q} 3=0.3$, mean $=0.2 \pm 0.1 \mathrm{kWh} / \mathrm{m}^{3} ;$ and median $=0.3 \mathrm{~kg} / \mathrm{m}^{3}, \mathrm{Q} 1=0.2, \mathrm{Q} 3=0.3$, mean $=0.3 \pm 0.1 \mathrm{~kg} / \mathrm{m}^{3} ;$ respectively) (Figure 5). This is logical because BF do not use active aeration to stimulate waste degradation and minimal energy is used in spreading of wastewater around the filters as sprinkling arms are typically hydraulically driven. This is consistent with Emmerson, Morse [30] who showed treatment plants with suspended, aerated processes consumed three times more energy and two times more $\mathrm{CO}_{2}$ emissions than a comparable BF process. Sludge production also was higher for AS plants (Figure 5), which is largely driven by greater biomass production and discharge in aerobic AS reactors compared with that from attached biofilms in BF reactors.

Analysis of the sources of associated $\mathrm{CO}_{2}$ production in the different treatment plants is shown in Figure 6. It can be seen that endogenous respiration (ER) within AS plants produced higher $\mathrm{CO}_{2}$ emissions than in BF plants (Figure 6). Even though BF plants considered almost twice the sludge retention time than in AS plants, the rate of cell decay considered in AS was six times higher than in BF (Table 1); a consequence of intensive aeration. Active aeration accelerates cellular growth, and can indirectly increase the amount of dead cells. For this reason, $\mathrm{CO}_{2}$ production, mainly due to ER of death cells, is higher in AS than in BF. Normally ER would be favoured in BF treatment due to the passive aeration and higher sludge retention times, but in this case the high rate of cell decay in AS overwhelms this effect. $\mathrm{CO}_{2}$ emissions produced by cell growth were not significantly different $(p>0.05)$ between BF and AS plants (Figure 6) indicating a similar performance. $\mathrm{CO}_{2}$ emissions generated by energy consumption were considerably higher for AS plants than for BF plants (Figure 6). Finally, $\mathrm{CO}_{2}$ emissions derived from energy use in AS plants were the highest among ER and growth; while in the case of $\mathrm{BF}, \mathrm{CO}_{2}$ emissions produced by energy used was equivalent to the ones produced by microbial growth. 


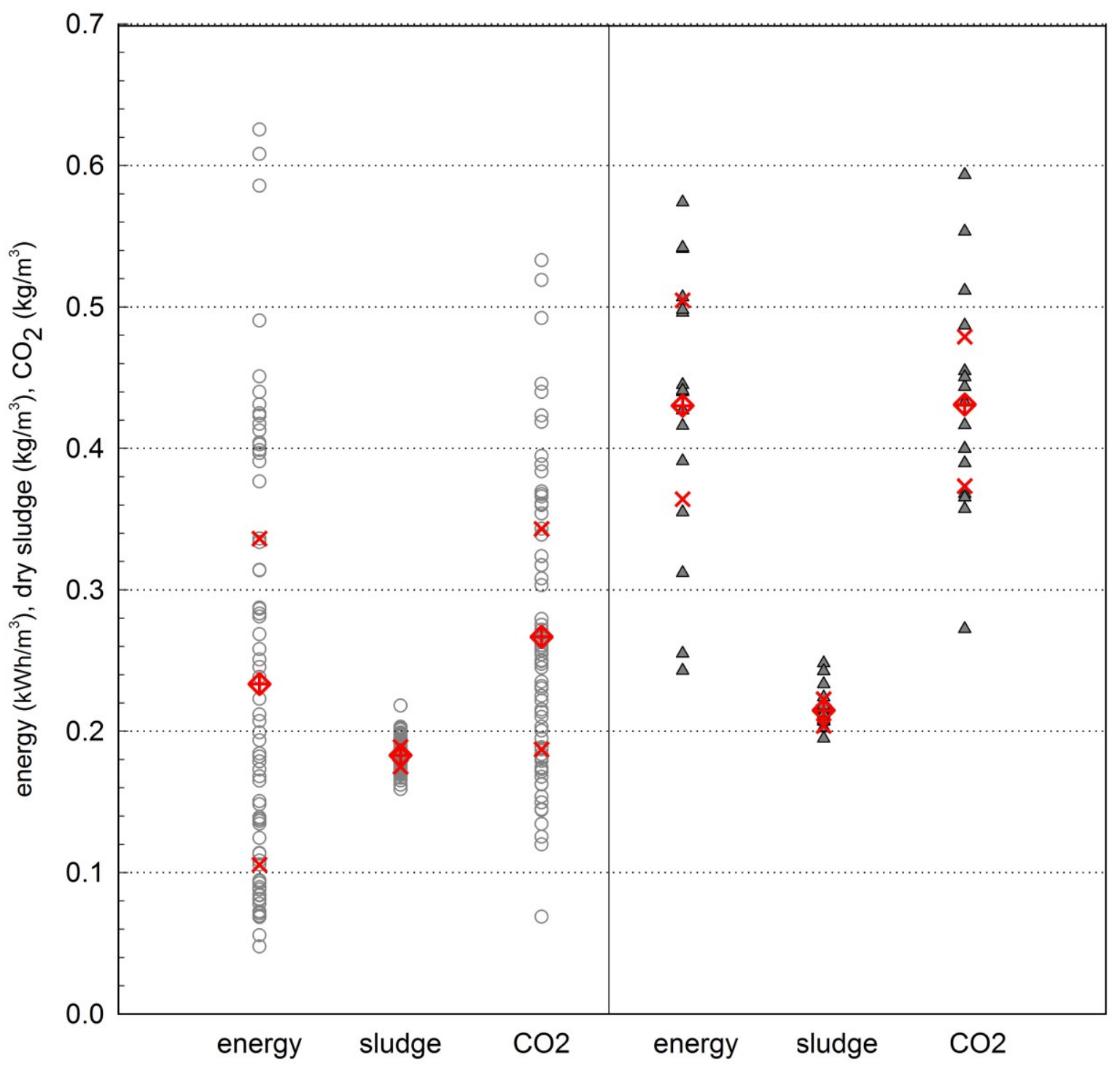

Figure 5: Interval plot for energy use, carbon dioxide and sludge emissions by activated sludge (AS, right) and trickling filters $(\mathrm{BF}$, left) treatment plants. Diamonds correspond to median values obtained for the region, crosses show the $1^{\text {st }}$ or $3^{\text {rd }}$ quartiles; raw data is also showed in the chart. Only wastewater treatment plants were evaluated; therefore energy and carbon dioxide offsets by anaerobic digestion of sludge were not considered. 


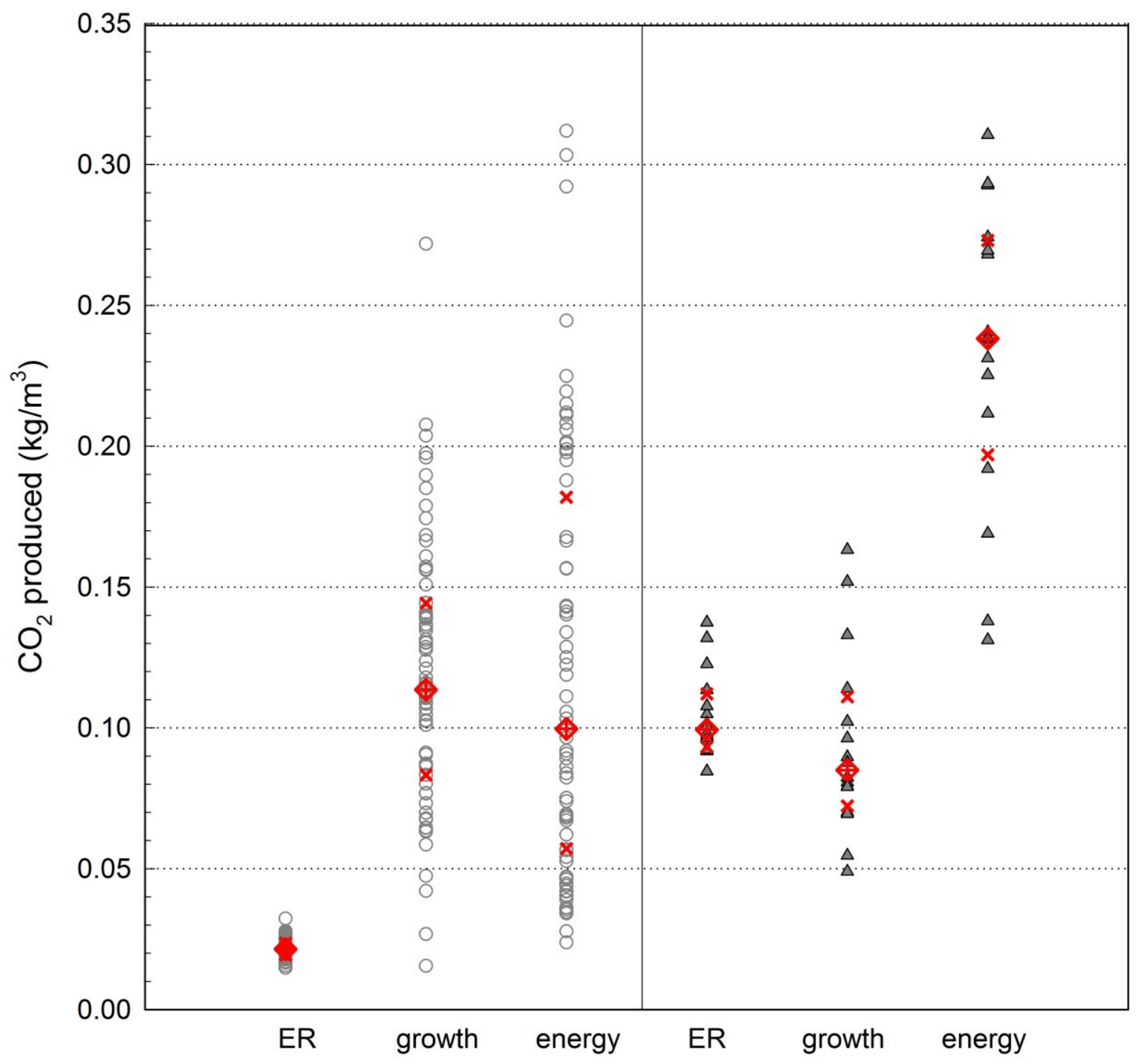

Figure 6: Carbon dioxide emissions due to different processes for wastewater treatment using activated sludge (AS, right) and trickling filters (BF, left). Diamonds correspond to median values obtained for the region, crosses show the $1^{\text {st }}$ or $3^{\text {rd }}$ quartiles, raw data is also showed in the chart. Only wastewater treatment plants were evaluated; therefore energy and carbon dioxide offsets by anaerobic digestion of sludge were not considered. ER stands for Endogenous Respiration.

\subsection{Sensitivity analysis}

Sensitivity analysis confirmed the model provided a coherent reflection of the network (Table 7). Hypothetical increases or decreases in assumed wastewater BOD proportionally altered 
$\mathrm{CO}_{2}$ emissions, an increase in $\mathrm{BOD}$ raised $\mathrm{CO}_{2}$ emissions and vice versa; whereas variations in $\mathrm{BOD}$ did not alter $\mathrm{CO}_{2}$ emissions from pumping stations. Specifically, increasing BOD load by $80 \%$ to wastewater treatment increased energy use and $\mathrm{CO}_{2}$ emissions by up to $91 \%$ and $83 \%$, respectively (Table 7). Decreasing BOD load by $80 \%$, reduced energy required for treatment by $65 \%$ and $\mathrm{CO}_{2}$ emissions by $75 \%$ (Table 7 ). The changes in wastewater BOD did not alter trends in terms of energy use and $\mathrm{CO}_{2}$ emissions, implying the model is relatively insensitive to different initial assumptions.

Table 7: Sensitivity analysis performed in calculations done for wastewater treatment

\begin{tabular}{|c|c|c|c|c|c|c|}
\hline & Units & $\begin{array}{c}\text { Pumping } \\
\text { Stations }\end{array}$ & Treatment & Transport & $\begin{array}{c}\text { Anaerobic } \\
\text { Digestion }\end{array}$ & Overall \\
\hline \multicolumn{7}{|c|}{ Operating conditions } \\
\hline \multirow{2}{*}{ Energy } & $\mathrm{MW} / \mathrm{y}$ & 32,100 & 107,000 & 3,620 & $-70,900$ & 71,820 \\
\hline & $\%$ & 22.5 & 75 & 2.5 & -50 & \\
\hline \multirow[b]{2}{*}{$\mathrm{CO}_{2}$} & $t / y$ & 17,400 & 114,000 & 1,510 & $-2,230$ & 130,680 \\
\hline & $\%$ & 13 & 86 & 1 & -2 & \\
\hline Dry sludge & $t / y$ & & & & 30,700 & 30,700 \\
\hline \multicolumn{7}{|c|}{ Decrease of BOD by $80 \%$} \\
\hline \multirow{2}{*}{ Energy } & $\mathrm{MW} / \mathrm{y}$ & 32,100 & 36,600 & 2,400 & $-25,700$ & 45,400 \\
\hline & $\%$ & 45 & 51 & 3 & -36 & \\
\hline \multirow[b]{2}{*}{$\mathrm{CO}_{2}$} & $t / y$ & 17,400 & 28,300 & 964 & $-1,314$ & 45,354 \\
\hline & $\%$ & 37 & 61 & 2 & -3 & \\
\hline Dry sludge & $t / y$ & & & & 17,980 & 17,980 \\
\hline \multicolumn{7}{|c|}{ Increase of BOD by $80 \%$} \\
\hline \multirow[b]{2}{*}{ Energy } & MW/y & 32,100 & 184,000 & 4,880 & $-70,900$ & 150,480 \\
\hline & $\%$ & 15 & 83 & 2 & -32 & \\
\hline \multirow[b]{2}{*}{$\mathrm{CO}_{2}$} & $t / y$ & 17,400 & 206,000 & 2,530 & $-2,240$ & 223,690 \\
\hline & $\%$ & 8 & 91 & 1 & -1 & \\
\hline \multirow[b]{2}{*}{ Dry sludge } & $t / y$ & & 26,000 & & 30,700 & 56,700 \\
\hline & $\%$ & & 54 & & 46 & \\
\hline
\end{tabular}




\subsection{Outlook for the water industry}

Global energy demand calculations predicted wastewater treatment will increase by $44 \%$ between 2006 and 2030 [40], including increased demand for new wastewater infrastructure in developing countries. Much evidence suggests current approaches with its locked-in pieces of infrastructures are not sustainable [22] and some do believe that an energy neutral network can be achieved [11]. However it is vital for new developments and indeed retrofits to existing plants that energy demands and $\mathrm{CO}_{2}$ emissions within and from the wastewater networks are better understood. Unfortunately, limited real data exist for decision-making, especially from whole networks.

For the first time energy and emission data were compared among different operations and components in the NE region wastewater network, including 87 WWTPs and 196 pump stations. Overall, wastewater treatment itself was found to have greatest impact on $\mathrm{CO}_{2}$ emissions and energy costs. In particular, AS plants demanded considerably greater energy than BF plants, which is clearly reflected by differences in energy and carbon per wastewater treated across the region. Counties with a preponderance of AS versus BF plants, such as Tees Valley, required significantly greater amounts of energy per wastewater treated than Durham County, which is dominated by BF plants. Therefore, shifting treatment technologies towards BF plants and-or alternate options, such as anaerobic or photosynthetic waste technologies, could reduce energy use relative to current AS plants.

In reality, such grand changes are impractical for most current networks as this would require substantial investments in providing new infrastructures. However on-site biological and nonbiological routes could be available for retrofitting existing AS plants could be financially more viable [41]. Manning, Graham [22] recently showed there could be a significant economic advantage to retrofitting existing AS plants with a BF pre-treatment step, which would reduce the carbon load on the AS plant, reducing aeration energy use. They suggest this would be particularly cost-effective in retrofitting larger WWTPs. Velasquez-Orta [41] demonstrated that simultaneous cultivation of microalgae/bacteria in aerobic tanks helped reduce $\mathrm{CO}_{2}$ emissions, increased nutrient removal and sludge energy content without compromising treatment.

For newly installed wastewater infrastructures, such as in developing countries, considering technical options that use less energy and decrease $\mathrm{CO}_{2}$ emissions are less bounded. For 
example, in Cakir and Stenstrom [23] model, it was found that digesting anaerobically wastewater with $\mathrm{BOD}_{\mathrm{u}}$ concentrations higher than than $300 \mathrm{mg} / \mathrm{L}$ linearly decreased $\mathrm{CO}_{2}$ emissions as the $\mathrm{BOD}_{\mathrm{u}}$ strength increased. Monteith, Sahely [32] also reported lower $\mathrm{CO}_{2}$ emissions for anaerobic wastewater treatment $\left(0.013-0.061 \mathrm{kgCO}_{2} \mathrm{e} / \mathrm{m}^{3}\right)$ than for AS $(0.153-$ $0.280 \mathrm{kgCO}_{2} \mathrm{e} / \mathrm{m}^{3}$ ). Apart from a decrease in energy use, anaerobic biotechnologies may have additional benefits, such as co-digestion of organic wastes [42] and recovery of volatile fatty acids [43]. However, treatment performance of current anaerobic technologies for domestic wastewater treatment is emitting high levels of $\mathrm{CO}_{2}$. For this reason anaerobic treatment may be better combined with other technologies (i.e., balancing energy and treatment performance), including technological options using algal ponds or BFs. Another treatment option might be the use of reed beds. Dixon et al. [44] found $\mathrm{CO}_{2}$ emissions and energy use could be at least four times lower when using reed beds than aerated BFs. Although reed beds would require a large space, they are highly favoured by using plants as carbon sinks, as these do not require mechanical aeration.

Contrary to the study of two WWTP in California [10] our study showed that the highest energy was needed in centralised AS plants (Figure 7); however, Lundin, Bengtsson [45] reported that electricity requirements decreased per BOD load when using large scale plants instead of small scale plants. Manning, Graham [22] also found decentralisation being less attractive than initially apparent because of losses in performance efficiency versus scale. However, they reported that if one coupled decentralisation with more careful community planning and considered combined BF-AS plants, decentralisation can became more attractive. Therefore, large economies of scale are not always applicable, especially when only using conventional AS treatment plants. The level of decentralisation should be evaluated according to the topographic characteristics of the site and effluent loadings rather than only considering the economies of scale as shown in Eggimann, Truffer [46]. As communities expand, deploying thoughtfully decentralised treatment plants could facilitate the uptake of new treatment technologies that have low environmental impacts.

\section{Conclusions}

Wastewater treatment networks are engineered to remove pollutants from wastewater streams to a level that conforms to discharge quality standards and protects community health. However, as reducing $\mathrm{CO}_{2}$ emissions and energy consumption becomes more important, 
wastewater network design must now take into account additional sustainability factors. This work showed that counties with centralised wastewater networks not only use more energy for pumping wastewater (up to $30 \%$ of the county overall), but also for treatment, especially AS plants (up to $80 \%$ of the county overall), whilst counties with greater BF plants for less energy and emit less $\mathrm{CO}_{2}$ (Durham). AS plants used significantly more energy (median= 0.4 $\mathrm{kWh} / \mathrm{m}^{3}$ waste treated) and produced more $\mathrm{CO}_{2}$ emissions (median $=0.4 \mathrm{~kg} / \mathrm{m}^{3}$ ) that $\mathrm{BF}$ plants (medians: $0.2 \mathrm{kWh} / \mathrm{m}^{3}$ for energy, and $0.3 \mathrm{~kg} / \mathrm{m}^{3}$ for $\mathrm{CO}_{2}$ ). These differences are critical and identify specific network inefficiencies that can be targeted for change. Reducing energy use during biological treatment, either through retrofitting or alternate technologies, will have the greatest positive impact on reducing $\mathrm{CO}_{2}$ emissions and energy use. Therefore, retrofitting future developments of wastewater infrastructures should help on these inefficiencies; i.e., reducing reliance on AS plants, increasing BF and alternate plants, and minimising new sewer construction, possibly via greater WWTP decentralisation.

\section{Acknowledgements}

We appreciate the technical assistance and industrial insight of different managers and specialist in Northumbrian Water Ltd including Mrs. Bernie Glanville, Mrs. Holly Hutchinson, Mr. David Harker and Mr Alec Llewellyn. This work was partially supported by the EPSRC through the project titled: SECURE: SElf Conserving URban Environments (reference number: EP/I002154/1). OH was funded by EPSRC iBUILD: Infrastructure Business models, valuation and Innovation for Local Delivery (Ref.: EP/K012398/1). EPSRC had no involvement in the study design; collection, analysis and interpretation of data; writing of the report; or in the decision to submit this manuscript for publication with Applied Energy. 


\section{References}

[1] Heidrich O, Reckien D, Olazabal M, Foley A, Salvia M, Hurtado SDG, et al. National climate policies across Europe and their impacts on cities strategies. Journal of Environmental Management. 2016;168:36-45.

[2] United Kingdom. The Climate Change Act. In: II E, editor. UK: The Stationary Office Limited; 2008.

[3] Villarroel Walker R, Beck MB, Hall JW, Dawson RJ, Heidrich O. Identifying key technology and policy strategies for sustainable cities: A case study of London. . Environmental Development. 2017;21: 1-18.

[4] Tassou SA. Energy conservation and resource utilisation in waste-water treatment plants. Applied Energy. 1988;30:113-29.

[5] Rothausen SGSA, Conway D. Greenhouse-gas emissions from energy use in the water sector. Nature Climate Change. 2011;1:210-9.

[6] Venkatesh G, Brattebø H, Sægrov S, Behzadian K, Kapelan Z. Metabolism-modelling approaches to long-term sustainability assessment of urban water services. Urban Water Journal. 2017;14:11-22.

[7] Byrns G, Weatley A, Smedley V. Carbon dioxide releases from wastewater treamtnet: potential use in the UK. Engineering Sustainability - ICE publishing. 2012;166.

[8] Mcnamara G, Fitzsimons L, Horrigan M, Phelan T, Delaure Y, Corcoran B, et al. Life cycle assessment of waste water treatment plants in ireland. Journal of sustainable development of energy, water and environment systems. 2016;4:216-33.

[9] Longo S, d'Antoni BM, Bongards M, Chaparro A, Cronrath A, Fatone F, et al. Monitoring and diagnosis of energy consumption in wastewater treatment plants. A state of the art and proposals for improvement. Applied Energy. 2016;179:1251-68.

[10] Shehabi A, Stokes JR, Horvath A. Energy and air emission implications of a decentralized wastewater system. Environmental Research Letters. 2012;7.

[11] Wang H, Yang Y, Keller AA, Li X, Feng S, Dong YN, et al. Comparative analysis of energy intensity and carbon emissions in wastewater treatment in USA, Germany, China and South Africa. Applied Energy. 2016;184:873-81.

[12] Gu Y, Li Y, Li X, Luo P, Wang H, Robinson ZP, et al. The feasibility and challenges of energy self-sufficient wastewater treatment plants. Applied Energy. 2017;204:1463-75.

[13] Lee M, Keller AA, Chiang P-C, Den W, Wang H, Hou C-H, et al. Water-energy nexus for urban water systems: A comparative review on energy intensity and environmental impacts in relation to global water risks. Applied Energy. 2017;205:589-601.

[14] Nordlander E, Olsson J, Thorin E, Nehrenheim E. Simulation of energy balance and carbon dioxide emission for microalgae introduction in wastewater treatment plants. Algal Research. 2017;24:251-60.

[15] Cano R, Pérez-Elvira SI, Fdz-Polanco F. Energy feasibility study of sludge pretreatments: A review. Applied Energy. 2015;149:176-85.

[16] Corominas L, Foley J, Guest JS, Hospido A, Larsen HF, Morera S, et al. Life cycle assessment applied to wastewater treatment: State of the art. Water Research. 2013;47:548092.

[17] Sturm BSM, Lamer SL. An energy evaluation of coupling nutrient removal from wastewater with algal biomass production. Applied Energy. 2011;88:3499-506.

[18] Longo S, d'Antoni BM, Bongards M, Chaparro A, Cronrath A, Fatone F, et al. Monitoring and diagnosis of energy consumption in wastewater treatment plants. A state of the art and proposals for improvement. Applied Energy. 2016;179:1251-68. 
[19] ASCE. Failure to Act: The Economic Impact of Current Investment Trends in Water and Wastewater Treatment Infrastructure. Washington, USA.: American Society of Civil Engineers; 2011.

[20] Panepinto D, Fiore S, Zappone M, Genon G, Meucci L. Evaluation of the energy efficiency of a large wastewater treatment plant in Italy. Applied Energy. 2016;161:404-11.

[21] Ahammad SZ, Bereslawski JL, Dolfing J, Mota C, Graham DW. Anaerobic-aerobic sequencing bioreactors improve energy efficiency for treatment of personal care product industry wastes. Bioresource Technology. 2013;139:73-9.

[22] Manning LJ, Graham DW, Hall JW. Wastewater systems assessment. In: Hall JW, Tran, M, Hickford, A.J., Nicholls, R.J., editor. The Future of National Infrastructure: A System-ofSystems Approach Cambridge: University Printing House; 2016. p. 134-57.

[23] Cakir FY, Stenstrom MK. Greenhouse gas production: A comparison between aerobic and anaerobic wastewater treatment technology. Water Research. 2005;39:4197-203.

[24] Shiu HY, Lee M, Chiueh PT. Water reclamation and sludge recycling scenarios for sustainable resource management in a wastewater treatment plant in Kinmen islands, Taiwan. Journal of Cleaner Production. 2017;152:369-78.

[25] Chen S, Chen B. Urban energy-water nexus: A network perspective. Applied Energy. 2016;184:905-14.

[26] Singh P, Kansal A, Carliell-Marquet C. Energy and carbon footprints of sewage treatment methods. Journal of Environmental Management. 2016;165:22-30.

[27] Lorenzo-Toja Y, Alfonsín C, Amores MJ, Aldea X, Marin D, Moreira MT, et al. Beyond the conventional life cycle inventory in wastewater treatment plants. Science of The Total Environment. 2016;553:71-82.

[28] Ling-Chin J, Heidrich O, Roskilly AP. Life cycle assessment (LCA) - from analysing methodology development to introducing an LCA framework for marine photovoltaic (PV) systems. Renewable and Sustainable Energy Reviews. 2016 59:352-78.

[29] Bonamente EC, F. . Carbon and Energy Footprints of Prefabricated Industrial Buildings: A Systematic Life Cycle Assessment Analysis. . Energies. 2015;8:12685-701.

[30] Emmerson RHC, Morse GK, Lester JN, Edge DR. The life-cycle analysis of small-scale sewage-treatment processes. Water and Environment Journal. 1995;9:317-25.

[31] E.On. Fuel Mix. London, UK: E.On; 2011.

[32] Monteith HD, Sahely HR, MacLean HL, Bagley DM. A rational procedure for estimation of greenhouse-gas emissions from municipal wastewater treatment plants. Water Environment Research. 2005;77:390-403.

[33] Metcalf \& Eddy., Tchobanoglous G, Burton FL, Stensel HD. Wastewater engineering : treatment and reuse. 4th ed. Boston: McGraw-Hill; 2003.

[34] Kong MF, Yang PY. Practical design equations for trickling-filter process. Biotechnology and Bioengineering. 1979;21:417-31.

[35] Defra. Guidelines to Defra/DECC's GHG conversion factors for company reporting,. 2011.

[36] Quaschning V. Renewable energy and climate change. Chichester, United Kingdom: John Wiley \& Sons Ltd. ; 2010.

[37] Panter K, Rawlinson D. Energy prices and carbon footprint cause a reversal of raw sludge drying in favour of advanced digestion with thermal hydrolysis and cake recycling in a number of UK plants. Residuals and biosolids. 2010:974-82.

[38] ONS. Population statistics in England and the United Kingdom. United Kingdom: Office for National Statistics; 2012.

[39] Defra. Wastewater treatment in the United Kingdom: Implementation of the European Union Urban Wastewater Treatment Directive - 91/271/EEC. London: Department for Environment, Food and Rural Affairs; 2012. 
[40] WWAP. The United Nations world water development report 4: managing water under uncertainty and risk. In: Programme) WWA, editor. Paris: UNESCO; 2012.

[41] Velasquez-Orta SB. Alternatives for energy produciton in aerobic wastewater treatment facilities. Water Science \& Technology. 2013;67:2856-62.

[42] Mattioli A, Gatti GB, Mattuzzi GP, Cecchi F, Bolzonella D. Co-digestion of the organic fraction of municipal solid waste and sludge improves the energy balance of wastewater treatment plants: Rovereto case study. Renewable Energy. 2017;113:980-8.

[43] Zacharof MP, Lovitt RW. Recovery of volatile fatty acids (VFA) from complex waste effluents using Water Science \& Technology. 2014;69:495-503

[44] Dixon A, Simon M, Burkitt T. Assessing the environmental impact of two options for small-scale wastewater treatment: comparing a reedbed and an aerated biological filter using a life cycle approach. Ecological Engineering. 2003;20:297-308.

[45] Lundin M, Bengtsson M, Molander S. Life cycle assessment of wastewater systems: Influence of system boundaries and scale on calculated environmental loads. Environmental Science and Technology. 2000;34:180-6.

[46] Eggimann S, Truffer B, Maurer M. To connect or not to connect? Modelling the optimal degree of centralisation for wastewater infrastructures. Water Research. 2015;84:218-31. 